\title{
State-religious relations in modern Russian society
}

\author{
Dari Tsyrendorzhieva $^{1}$, Kseniya Bagaeva ${ }^{1 \mathrm{a}}$ \\ ${ }^{1}$ Buryat State University, 670000, Smolin str. a 24, Ulan-Ude, Russia
}

\begin{abstract}
The paper discusses main aspects of the modern relations between the state and religion in the Russian society. It argues that the term 'state-religious relations' most fully reflects the essence of these interactions. The relevance of this topic is confirmed by social transformations that led to changes in all spheres, including a religious one. The authors are especially concerned with a tendency of clericalism that manifests itself in the society. The paper discusses main models of state-religious relations. On the basis of that it has been concluded that a cooperative model of state-religious relations functions in Russia, but with its own characteristics. The paper describes the nature of the relationship between the state and religion, using an example of the educational sphere that most clearly represents these links. In addition, the authors indicated factors of convergence of the state and religion providing positive and negative sides of that process. The conclusion is that, nowadays, new state-religious relations are developing in Russia, since the last models have been exhausted
\end{abstract}

\section{Introduction}

The society is a complex system of relations and interactions that may be economic, political, cultural, legal, etc. Social interactions should also include a statereligious one that is an integral part of any society nowadays.

Nowadays, the religion plays an important role. The results of studies conducted by the Department of Social and Political Studies of the Institute of Social and Political Studies of the Russian Academy of Science (ISPS RAS) may support that claim. Monitoring data show that starting from 1995 there is a constant increase in public confidence in the Church. The highest level of confidence was in 2012 - 55 per cent of respondents trust the Church. "Moreover, after a long break (since 1999) the Church overtook the presidency by the level of confidence" [1].

It turns out that in regard to the religion and state, people prioritize religious values. Therefore, "by the level of confidence that is given to various social and political institutes, the Church is one of the leaders along with the power institutes and army. Moreover, the Church's social authority is recognized by a believing and also by unbelieving part of society that demonstrates its big potential influence on the Russian social climate" [2].

According to the survey conducted by the Russian Center for Public Opinion (VTsIOM) on June 242015 , the following picture emerges - the majority of Russians (64 per cent) are for the preservation of the principle of secularism over religion. Moreover, 47 per cent believe that the Church should in no way interfere in the politics, but influence the morality. At the same time, 47 per cent approve the established relationship between the state and religion. Therefore, according to more than a half of respondents ( 57 per cent), the Russian society is secular and it should remain as such.

Table 1. State-religious relations in Russia.

What do you think, should there be relations among a Church and a society, a state?

(the closed question, one answer, \%)

\begin{tabular}{|c|c|c|c|c|}
\hline & 2009 & 2013 & 2014 & 2015 \\
\hline & 27 & 31 & 30 & 32 \\
\hline $\begin{array}{c}\text { The Church should deal } \\
\text { with the problems of faith } \\
\text { and religion, not } \\
\text { interfering in the life of } \\
\text { society and state }\end{array}$ & 43 & 44 & 50 & 47 \\
\hline $\begin{array}{c}\text { The Church should be } \\
\text { actively involved in } \\
\text { discussion and solution of } \\
\text { the problems of modern } \\
\text { society and state }\end{array}$ & 17 & 17 & 15 & 14 \\
\hline No answer & 14 & 7 & 5 & 7 \\
\hline
\end{tabular}

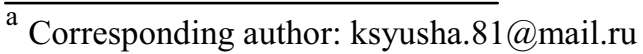


The opinion of Russians on what relations between the state and religion have to be build is shown in table 2 [3].

Table 2. State-religious relations in Russia.

And what are the actual relations between the and the society/state in our country now? (the closed question, one answer, \%)

\begin{tabular}{|c|c|c|}
\hline & 2012 & 2015 \\
\hline $\begin{array}{c}\text { Today the Church has an insufficient } \\
\text { influence on the life of the society and } \\
\text { the state, it ought to actively participate } \\
\text { in the discussion/decision important for } \\
\text { the country issues }\end{array}$ & 43 & 18 \\
\hline $\begin{array}{c}\text { Today the Church is too actively } \\
\text { involved in the life of society, the } \\
\text { Affairs of the state, it ought to pay } \\
\text { more attention to spiritual and moral } \\
\text { issues }\end{array}$ & 19 & 18 \\
\hline No answer & 14 & 17 \\
\hline
\end{tabular}

The second table shows a real situation in the statereligious relations sphere from the point of view of respondents [3].

However, we argue that despite the fact that Russia declares itself as secular there is still penetration of the religion into social spheres. On the one hand, there is a process of clericalism, on the other - secularization of the Church. After all, since the 2000s, military and prison chaplains appear. That suggests the trend of clericalism is common not only for the Orthodox and for Muslim, but also for some other rising branches of the Protestantism and even new religious movements [4]. The nature of the state-religious relations might vary depending on the nature and the type of the religion. That is why historically there were many those models of interaction, and the degree of the state-religion's interpenetration varied.

Therefore, the purpose of this study is to explore characteristics of the state-religious relations at the present stage. The achievement of that goal models of the state-religious relations should be discussed in their diversity. In addition, we will discuss a very important part of the state-religious relation - education that in many states ideally fits into the fabric of the statereligious relations. After all, as it was rightly pointed out by Steven Kettel, "the findings show that countries with a state religion have substantially lower levels of freedom across a range of measurements than countries with no state religion. The absence of any clear interrelations of levels of human development, religious diversity and religiosity indicates a key causal role for the institutional mechanics of a state religion itself" [5].

\section{Materials and methods}

Various fields of science study relationship between the state and confessions. Most of the research is dedicated to a historical aspect of the state-church relations. It is characterized by a description of specific facts on relationship between the state and various churches. For historical study it is also important to see how these relations developed in different periods. There are many works on sociological and legal aspects of such relations. This paper discusses the problem of the state-religious relations in terms of social philosophy. That will allow, while considering the essence of the religion, analyzing the significance and functions of the religion towards the state and society.

In regard to the study of the state-religious relations the basis is a dialectical method. It was used here to consider the state-religious relations in real history. A comparative method allowed comparing different models of the state-religious relations. It also helped to identify the features of development and interaction of these aspects of social life in different countries. In addition, theoretical and predictive methods helped to determine the prospects of modern state-religious relations.

The modern view on the relationship between the state and religion is very heterogeneous. However, in our opinion, there are some views that should be addressed at. Firstly, it is necessary to clarify the use of the term "state-religion relations". Nowadays, such terms as "state-church relationship", "state-confession relationship" are used. In our opinion, the term "statereligion relations" is the most optimal and appropriate for the studies in that sphere because it conveys their mutual change and impact on society. We argue that this term reflects relationship between the state and religion more adequately. The relationship between the state and religion are historically changing forms of interconnections of the state institutions and religious institutional structures.

The sphere of education may serve as one of the examples of state-religious relations that shows the level of religious influence on the state. We see nowadays that there are more Orthodox and Muslim schools being established. There is Buddhist University in Ivolginsky area, Buryatia. Since 2008, religious educational institutions have a right to realize licensed educational programs in accordance with the requirements of federal educational standards. Theological academies, universities, seminaries, and madrassas receive state accreditation on the relevant areas of training (specialties) without receiving a state status of the institution as a whole. Accordingly, graduates of the religious schools, who have successfully completed their studies in accredited educational programs, receive state diplomas [6].

In modern world, there are many varieties of placing religion and designating its role in the education. There is a range of studies on that subject including the work of Volodina N.V. "Legal systems of the state-confessional relationship" [7]. That work treats the principle of separation of church and state as a basis for state-religion relationship's classification, including educational sphere. 
The study of Mchedlov M. P. [8] can be named among the works devoted to the study of the role of the religious factor in the state-religion relationship.

American scholar K. Durem studies religion quite thoroughly. He uses a degree of religious freedom as a basis for his study. He estimates that criterion as a level of the state's impact on the religion and the degree of connection between the state and religious institutions [9]. Therefore, we will also adhere to this viewpoint in our study.

In accordance with this, it is necessary to highlight the following types of the state-religion relations: cooperative and separation models. The first model is represented in the USA, France, while the second model is prevalent mainly in the European countries (Italy, Germany).

According to M. Mchedlov, "a separation model of the state-confession relationship declares liberal standard of religious freedom in its entirety. The state sees religious life as a free market that is regulated only by competition. In fact, however, that market is far from being free" [8]. While the cooperative model, also referred to as a "special kind of partnership", involves preservation of the religious freedom. Every citizen can freely choose his/her religious and worldview orientation without running risk of being subjected to any discrimination. The cooperative model includes several statuses of the religion in the state. First, the status of the state religion that offers a range of privileges in property, legal, financial, educational, and political spheres [10]. Second, there are contractual relations between the state and religion in some states. Finally, the third type of relations implies religions with an officially recognized (traditional) status.

Thus, comparing the main models of the statereligion relation it becomes clear that the degree of separation between the state and religion may vary. Therefore, we will look into strengths and weaknesses of these models. That will allow understanding what should become the main concept of the state-religion relation in the Russian society.

\section{Conclusion}

Looking into the discussed models it can be argued that their formation was based on the idea of religious freedom, tolerance, and state's neutrality toward religion. All of them are implemented in practice, although not in a pure form. For example, the separation model demonstrates clearly a complete separation of the state from religion. The role of religion is reduced to the institution that performs social functions. However, as M. Mchedlov notes, "real dominance in the confessional sphere is set by those structures that have the most financial and organizational capabilities and whose "goods" are more popular in the "consumer society" [8]. Therefore, various myths of a quasi-religious character become common.

The cooperative model is characterized by the fact that "the state has a right of differentiated treatment to different confessional communities that receive a different level of authorities" [8]. The strength of this model is the establishment of special partnership with the relative independence of the sides.

The thirds model is a moot point in what religion can be called traditional. Very often, the debates on that issue move from a religious to political sphere. Because traditional religions receive some preferences from the state.

Despite the fact that there are some fundamental principles for the state-religion relations, the mechanism of implementation strongly depends on national and cultural characteristics. Therefore, it is difficult to apply any particular model to the Russian state. This is due to certain reasons.

For a long time there was a symphonic model of the state-religion relations in Russia (that is, between the Russian Orthodox Church and the state). The idea of "symphony" implied mutual freedom of the state and the Russian Orthodox Church. That did not mean their separation, but rather the Church became a part of the state. Other confessions were in a quite straitened position.

In the history of the state-religion relations in Russia there were periods of anti-religion measures and actions. "The collapse of the Soviet regime lifted those restriction from religious life and activities that were imposed by the Soviet secularization. Religion started to play an increasingly important role in the Russian society" [11].

Due to the special Russian cultural and historical conditions, it is possible to identify several models at the same time. On the one hand, being a secular state, Russia is trying to build a model. In reality, however, there is the cooperative model with the state Russian Orthodox Church and traditional religions with a number of advantages.

Since the 2000s, at the president V. Putin's suggestion, there is an active involvement of the religion into the solving of moral issues. If we trace the dynamics, the religion impact increases and extends up to the educational sphere. Therefore, in our opinion, it is difficult to identify a sphere that can be called purely secular or purely religious.

The questions of studying religion at secondary schools were discussed at recent XXIV International Christmas Readings (January 25-26, 2016, Moscow). The Metropolitan of Rostov and Novocherkassk Mercury states, "It is remarkable that the percentage of "Fundamentals of the Orthodox Church" choice increases in the course "Fundamentals of Religious Cultures and Secular Ethics" in the 4th grade" [11]. He adds that there are serious developments to extend the course for a longer education period. "The number of trained teachers increases. The situation is being monitored. Eparchies are being assisted. And here I must say thanks to the Ministry of Education and Science for a constructive dialogue with the Church" [12].

In this regards, on the one hand, the supporters of implementation and further development of that course in Russian schools account for its positive impact on children's wellbeing. So, the Bishop of Dushanbe and Tadzhikistan Pitirim argues in his report "Christian and Secular Education: Past and Present" that "modern 
efforts of traditional religious associations, aimed at forming religious consciousness that is able to resist sin's aggression, are capable of stopping a development of hatred and intolerance in the society" [12].

On the other hand, some do rightly fear of the strengthening role of the Church in society. O.V. Martyshin argues that "Expansion of the religion into the sphere of state education increases" [13].

It should be noted that state officials often demonstrate a commitment to the religious traditions, especially to the Orthodox Church traditions, i.e. the presence of the president and other officials at religious events and celebrations. That finds all possible attention in the media. It seems that such behavior (that shows the convergence of secular and religious) is connected with mutual benefit for the state and the church.

What is the benefit? Firstly, the state tries to strengthen secular laws with the help of religion by supporting them with religiousness and sanctity. Secondly, religious is closely connected with national in Russia. Therefore, in rapprochement with the Church the state tries to strengthen the national identity. Finally, religion always served as an ideological force on the international political arena. N. Volodina points out the importance of the participation of "the Russian Orthodox Church and other traditional confessions in solving social problems (combating alcoholism, drug abuse, and other socially dangerous diseases), preservation and protection of public morals" [7,]. In our country, the loss of the communist ideology led to the gap, of which the authorities are quite aware. The desire to get closer to the state is also understandable from the position of the religious organizations. Firstly, this is due to material interests because the state finances the construction and reconstruction of churches, religious projects, etc. Secondly, the support of the state's missionary activities is possible with the help of the media. Finally, the state and religion cooperation may bring some preferences to the church (that happens for the Orthodoxy nowadays) as well as possible mitigation of law or even legislative changes to strengthen the church.

Thus, the state-religion relations give some positive effect for religious organizations as well as for the state. It is possible to identify some negative tendencies, however, such as the failure to comply with the principle of secularity of the Russian state. That manifests itself in the absence of equal treatment for each confessions.

Therefore, it should be noted that the state-religious cooperation should have its limits, beyond which there are irreversible consequences and the Russian society is not ready for them yet. To avoid that, Russia should take into account an experience of world practice of statereligion relations. It is even possible to create a unified concept for the regulation of state-religion relations in line with the legal framework and taking into account cultural and national characteristics. Even more, the stage of mutually beneficial cooperation goes to an end. It is possible to state that a new form of state-religion relations is being formed in Russia nowadays that, unfortunately, does not take into account the world experience.
Referring to the experience of foreign countries in building relationship with religion, the Russian state should take into account their experience in legal regulation. But it should avoid the blind copying of the models due to the cultural and national differences. In our opinion, the concept of state-religion relations should be build in accordance with poly-confession of the state that is directed at social partnership and revival of ethical culture. That will help to avoid excessive clericalism. In the education sphere, it is necessary to ensure a cultural approach but not religious propaganda.

It is obvious that the state should not constantly interfere into the religion. Therefore, "the search for appropriate forms of state-religion relations should aim at equal protection of interests, which is not identical to neutral treatment: in some situations, conditional state support for religious groups may be in the interest even of nonbelievers" [14]. The state and religion relationship is interaction that can be dangerous with its excesses. Therefore, it is necessary to respect a parity of religious and secular norms.

\section{References}

1. Yu.Yu. Sinelina, Socis, 10, 104-115 (2013)

2. M.M. Mchedlova, Socis, 12, 77-84 (2009)

3. Tserkov' i obshhestvo: vmeste ili porozn. Pressvypusk№2861,URL:http://wciom.ru/index.php?id=2 36\&uid=115295 (02.02.2016.)

4. A.G. Zaluzhnyj, Rossiya reformiruyushhayasya. Ezhegodnik, 7, 493-503(2008)

5. S. Kettel, Pol.and Rel, 6 (03), 538-569 (2013)

6. Federal'nyj zakon ot 28 fevralya 2008. № 14-FZ «O vnesenii izmenenij v otdel'nye zakonodatel'nye akty Rossijskoj Federatsii v chasti litsenzirovaniya i akkreditatsii uchrezhdenij professional'nogo religioznogo obrazovaniya (dukhovnykh obrazovatel'nykh uchrezhdenij), URL: http://www.garant.ru/hotlaw/federal/172372 (27.01. 2016)

7. N.V. Volodina, Pravovye sistemy gosudarstvennokonfessional'nykh otnoshenij, 461 (Izd-vo «Novyj indeks»), Moscow, 2009)

8. M.P. Mchedlov, Tolerantnost' (Respublika, Moscow,2004)

9. K. D'yurem, Perspektivy religioznoj svobody (Institut religii i prava, Moscow, 1999)

10. L.A. Morozova, Gosudarstvo i pravo. 3, 86-95 (1995)

11. A. Shishkov, Gosudarstvo, religiya, tserkov' v Rossii i za rubezhom, 2(30), 165-177 (2012)

12. XXIV Mezhdunarodnye Rozhdestvenskie obrazovatel'nye chteniya, URL: http://mroc.pravobraz.ru (01.02.2016)

13. O.V. Martyshin, Gosudarstvo i pravo, 7, 38-47 (2015)

14. P. Ryan, Int'1 J. Const. L., 12(2), 457-463 (2014) 